\title{
Problems of Architectural and Space-Planning Design of Urban Facilities for Industrial and Utility Purposes (by the Example of Moscow)
}

\author{
Alexandr Ivanovich Finogenov, Aleksey Vladimirovich Popov
}

\begin{abstract}
A modern composition of industrial and utility enterprises, intended for placement in the modern structure of large urban formations, is considered in the study. By the example of the planning design of a large urban territory of Moscow, a set of unresolved problematic issues characteristic of modern urban planning practices associated with the unsatisfactory architectural, planning and transport organization of public utilities in relation to public residential areas of the city is revealed. A fundamentally new methodical approach to the design of urban utility enterprises based on the formation of cooperative industrial and utility complexes as part of groups of specialized low-waste modular-type enterprises intended for system placement in the structure of developing cities is proposed.Subject of study: the problems of planning design of modern urban development and urban facilities for industrial and utility purposes. Results: a number of problems are identified in the system of industrial and utility facilities of large urban formations in Russia; a number of architectural and urban planning measures, potentially leading to the improvement of the functioning of the system of such objects, are proposed; a model of the functional design of an interdistrict industrial and utility complex (IIUC) of a new type is proposed as part of a number of technologically-connected industrial facilities and a system of economic interrelations with designated territories of the supported residential development of the city.
\end{abstract}

Index Terms: architectural and planning organization, environmental situation, industrial and utility enterprises, interdistrict industrial and utility complexes, low-waste technologies, short transport links, urban development, urban enterprises.

\section{INTRODUCTION}

At present, the development of large cities in Russia is largely acquiring an extensive nature due to the expansion of the boundaries of built-up areas, and the increasing complexity of the functional planning design of urban structures [1]. The trend in the urban space development is due to the intensification of the development of residential, social, business, recreational, commercial, and transport objects while at the same time reducing the development rates of the industrial potential of the city. Therewith, a modern scheme of functional zoning of the city is being

Revised Manuscript Received on October 30, 2019

* Correspondence Author

Alexandr Ivanovich Finogenov*, Architecture Department, Moscow State University of Civil Engineering, Moscow, Russian Federation.

Aleksey Vladimirovich Popov, Architecture Department, Moscow State University of Civil Engineering, Moscow, Russian Federation.

(C) The Authors. Published by Blue Eyes Intelligence Engineering and Sciences Publication (BEIESP). This is an open access article under the CC BY-NC-ND license (http://creativecommons.org/licenses/by-nc-nd/4.0/) formed, where its industrial and utility areas remain within their historically established borders with the increase in territory, density and relative remoteness of public residential buildings, the length and complexity of transport communications. Large cities with a million-plus population, such as Moscow, St. Petersburg, and Ekaterinburg, can serve as the examples of such an imbalance [1]-[4].

\section{METHODS}

The industrial and utility complex of a modern large city has a sophisticated structure and is formed, as a rule, in the following three groups of specialized facilities:

- enterprises of the heat and power complex (thermal power stations, RTSs, city and regional electric substations);

- water supply and sanitation complex (sewage treatment plants, main network facilities);

- a complex of repair and construction, storage, road maintenance and sanitary facilities of the city.

The first two groups of enterprises are characterized by a relatively independent ordered settlement scheme of placement in the territorial structure of the city, using off-street overhead or underground engineering communications systems. The third group is represented by urban utilities of various functional and departmental affiliations. These enterprises are directly related to the maintenance of residential and public areas of the city, objects of road and transport communications. First of all, these include: road repair enterprises; asphalt-concrete and mortar-concrete units; enterprises and warehouses for processing construction and demolition waste; city bases and warehouses of construction and inert materials; snow-melting points and storage bases for anti-icing materials; enterprises for sanitary cleaning of the city (waste incineration and recycling plants, waste disposal stations); bases for storage and repair of transport utility equipment; urban construction industry enterprises. In contrast to the first two groups, these enterprises are characterized by a significant annual volume of processed materials, intensive freight traffic, the use of only land-based freight and large-capacity technological vehicles. Only within the boundaries of the territory of Moscow, the annual transportation volumes of solid household waste exceed 5 million tons, and the transportation volumes of nonmetallic (raw materials) building materials, construction and demolition waste, industrial waste amount to tens of millions of tons. 
In this regard, the listed objects require a fundamentally thought-out systematic approach to the design and placement in the structure of the city. In essence, they should be satellite enterprises of most of its territorial-planning formations.

In this regard, an analysis of the example of Moscow and other large cities shows a violation of the principle of balanced development of the abovementioned industrial and utility facilities of the third group. On the one hand, according to their functional purpose, they should be directly related to specific objects of development and maintenance of the city, represented, as a rule, by socially-residential areas, with appropriate maintenance of environmental quality and sanitary-ecological living conditions. On the other hand, the modern structure of these enterprises is characterized by the absence of a geographically orderly system placement in relation to the main service areas, without a clear link to the existing and, especially, to the prospectively developing peripheral structures of the city [2], [5]. This imbalance is aggravated by the lack of geographically thought-out cooperative links between individual functional units of the economic complex, an underestimation of the use of low-waste energy-saving technologies, the use of outdated open methods of processing and storing raw materials and equipment [6].

\section{RESULTS ANALYSIS}

The dispersion and remoteness of enterprises of the third group from specific service areas, in the context of objectively increasing industrial needs of the city, causes a sharp increase in the intensity of intra-urban and non-urban road traffic for the transportation of materials and waste. This exacerbates the complicated problems related to the load relief of the overloaded intracity and exit transport routes, contributes to the sustainable deterioration of the ecological situation of the city [7], [8].

Fig. 1 shows a typical operating model of the planning design of urban utility facilities for the collection, transportation, processing and removal of solid household waste (SHW) outside Moscow to the landfill by the example of the North-East Administrative District (NEAD), Moscow, in a conventional form. This district is one of the largest in terms of its territory (about $100 \mathrm{sq}$. $\mathrm{km}$ ), the number of the resident population (more than 1.2 million people), the density of buildings and the volumes of solid waste accumulated (about 500 thousand tons of SHW per year).

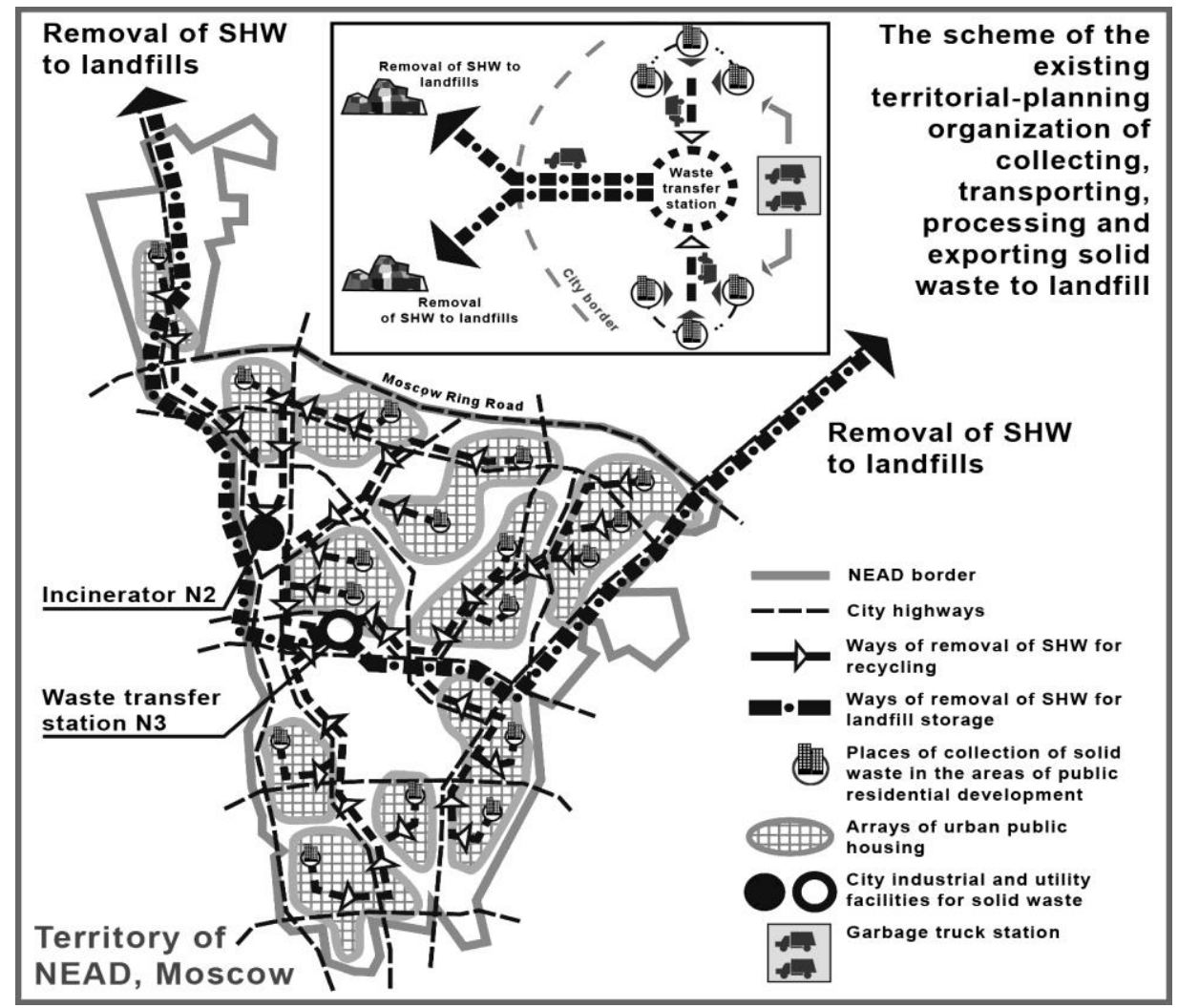

Fig. 1. Planning Organization Scheme For Urban Utility Facilities (By The Example Of The NEAD, Moscow) For Collecting, Transporting, Processing And Exporting Solid Waste To Landfill (An Example Of The Lack Of Mutual Coordination In The Location Of Urban Public Utilities And The Main Arrays Of Community Housing)

Considering the obviously critical values of the parameters, the graphical model shows the fundamental discrepancy between the current scheme of the planning loscation of the main industrial waste recycling facilities and the number and degree of remoteness of large arrays of community housing units with MSW collection sites. Moreover, the extreme irrationality and excessive length of transport cargo flows on the delivery of waste for recycling with the subsequent removal of solid waste or residues from their processing outside the city to landfill sites is obvious [9].

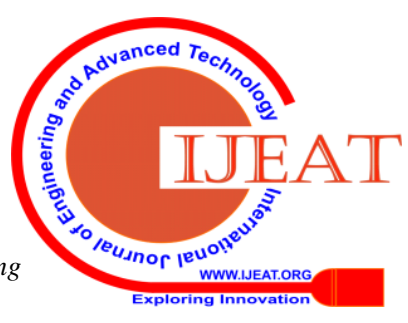


At the same time, only intracity daily large-capacity transport routes associated with the transportation of waste in the complex street-road network of the district make up tens of kilometers, which contributes to sustainable air pollution and contradicts the main goal of public utilities - maintaining the necessary sanitary condition of the urban environment [10]-[13].

Similar deficiencies are characteristic of the geographical location and functioning of most of the others of the above listed municipal facilities of the district.

This suggests that the existing structure and territorial organization of industrial and utility enterprises of the third group currently do not closely correspond to the complex urban situation of the city of Moscow, and are even less adapted to the conditions of the planned active reorganization of urban industrial zones, the rational use of their territories and citywide transport communication links [14].

It should be noted that the model presented in Fig. 1 shows that SHW processing facilities are provided for placement only as part of two of the 29 industrial zones of the North-Eastern District, which dramatically worsens the conditions of accessibility for daily sanitary maintenance of territories.

In accordance with the State Program for the Development of the City of Moscow in the Area of Urban Planning Policy, it is planned to carry out comprehensive work on the reorganization and development of the city's territories, including industrial and utility territories [15]-[17]. At present, the relevant design works are being carried out at an intensive pace, the purpose of which is to find additional reserves for the development of the city, to optimize the use of territories, in some cases, their functional orientation, and to reduce the boundaries of occupied areas. As practice shows, such works, in some cases, are carried out without taking into account the integrated development of utility facilities [2], [5].

In this regard, it is fundamentally important to actively include in the terms of reference the complexes of municipal enterprises, balanced in composition and size of the territories supported.

Another milestone in the preparation of projects for the reorganization of industrial zones is the maximum preservation of existing railway inputs for their effective use when locating newly formed complexes of utilities. This would dramatically reduce the volume of intracity traffic for the delivery of raw materials and removal of waste, would reduce the traffic load on the intracity highway and would contribute to the sustainable improvement of the ecological situation in the city.

The analysis shows that, to date, in Russia and abroad, for certain types of urban enterprises for industrial and utility facilities, positive experience in designing and construction has been gained with the use of high-tech and architecturally expressive solutions. The examples are the individual objects of mechanized warehouse structures of closed type for the storage and handling of nonmetallic materials for placement in the conditions of the city; compact and compositionally expressive constructions of plants and installations for the production of asphalt concrete and concrete mixes; integrated storage and maintenance of cleaning and garbage vehicles, solved in the volume of a single interlocked building; new incineration and recycling plants providing high architectural and sanitary-ecological quality of the solutions used; mobile complexes for the processing of construction waste, worn-out vehicles, etc.

However, in domestic practice, some successful design solutions, as a rule, do not provide for compact joint and, especially, cooperative placement of the listed objects, which is a necessary condition given the current shortage of free urban areas and the intensification of industrial programs [18].

It is obvious that it is expedient to associate the new stage of designing urban utility facilities with the formation of a system of local cooperative interdistrict industrial and utility complexes (IIUC - the authors' abbreviation) in the form of groups of unified utility facilities intended for reuse, designed for short radii of transport service within limited territorial planning formations of the city.

A prerequisite should be the use of high-tech, resource-saving technologies with minimal waste disposal, deep integrated processing of raw materials and construction waste, cooperative engineering support, as well as functional interspecific cooperation of facilities for industrial programs. At its core, such interdistrict complex should form geographically accessible and sustainable centers for the application of social labor [19], [20].

As an example, Fig. 2 shows the model of the recommended functional organization of the IIUC of a new type as part of a number of technologically-connected industrial facilities and a system of economic interconnections with the assigned territories of the supported urban residential utility development. 


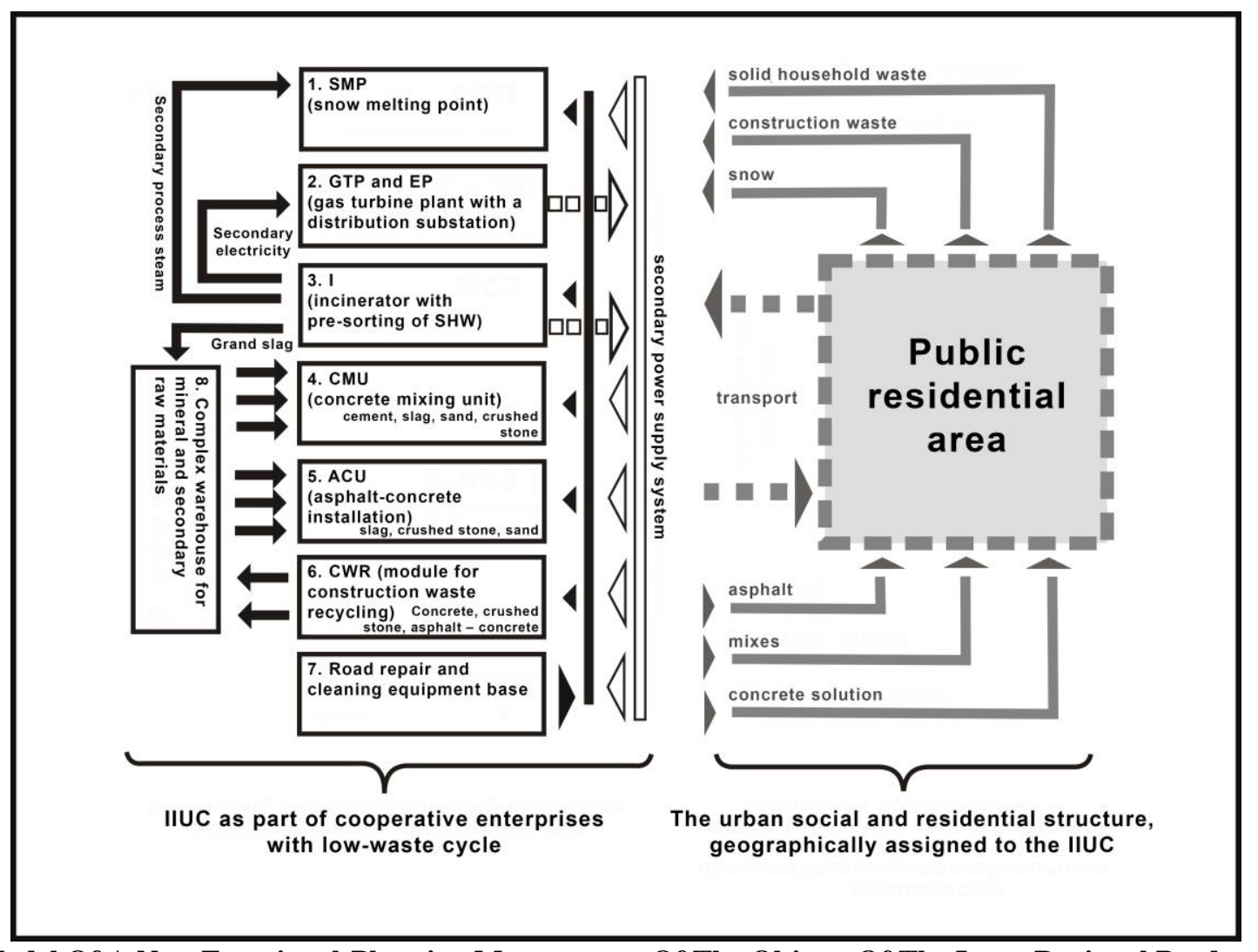

Fig. 2. Model Of A New Functional-Planning Management Of The Objects Of The Intra-Regional Production And Utility Complex Associated With The Settlement-Fixed Territorial And Public Residential Development Of Large Cities

As an example, the IIUC is presented in the structure of nine construction and technological conversions. The operation of the complex is based on the organization of a flexible autonomous power supply, which is ensured by introduction into its structure of an independent facility - an energy gas turbine plant with a distribution electric substation, which is complemented by a highly environmentally friendly building and technological module of the incinerator (I) with SHW pre-sorting. This module, due to its year-round operating cycle, is an additional source of electricity production and process steam required for the operation of related IIUC facilities, for example, an asphalt mini-plant and concrete products production plant module. In winter, secondary heat and energy resources of I should be used for technological needs of another related construction and technology module - a snow-melting point (SMP), which as part of the new interdistrict complex (IIUC) becomes geographically independent of the city-wide main sewers and as such it can serve any settlement-based area of the city at the location of the main IIUC [21]. Another important functionally related element of the IIUC can be a module for accommodating road repair and harvesting equipment in a compact and multi-tiered version, which, as shown in Fig. 2, comprehensively serves all the technological redistribution of the IIUC, as well as all types of transport freight traffic within the boundaries of the served public-residential zone of the city. An indispensable functional element of the IIUC should be a highly mechanized complex warehouse of nonmetallic raw materials and secondary materials from the processing of construction and SHW waste, for which the use of multispan closed highly mechanized storage facilities is environmentally sound. As can be seen from the model in
Fig. 2, this integrated resource-saving warehouse complex with extremely short leverage can fully ensure uninterrupted operation of the majority of production modules of the repair and construction and road designation as part of the placed IIUC. Of course, the actual composition of the IIUC objects and its planning organization will largely be determined and calculated depending on the composition and type of the specific territorial-planning formation of the city (as an object of industrial and utility service).

\section{CONCLUSION}

In general, the outlined areas predetermine a new topical area in conducting targeted integrated design and experimental studies to improve architectural and typological solutions of facilities that are part of the proposed IIUC.

This problem is basically interdepartmental in nature; accordingly, its solution requires joint efforts of specialists from a number of areas: technologists, planners, architects, designers, economists, sanitary doctors, and environmentalists [22]. The purpose of the research should be the development of rational architectural and construction solutions for buildings and structures based on the principles of single-level and vertical blocking, the formation of universal building-technological modules for the conditions of their parallel deployment in various parts and areas of the city, the application of low-waste high-ecological technologies and equipment ensuring minimal borders sanitary protection zones [23], [24].

Published By:

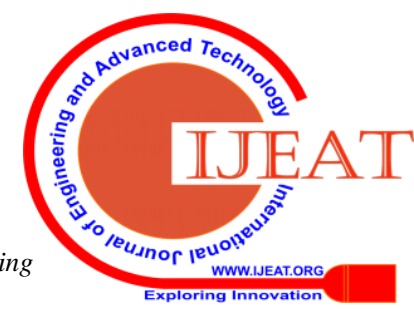


The implementation of these studies will reflect a fundamentally new methodological approach in the design of urban residential and industrial-utility areas, united by a single approach in the system placement of IIUC intended for wide use within the existing and future urban development, including within the boundaries of urban industrial zones that are reorganized or planned for liquidation. The proposed approach currently is of special relevance not only for Moscow and the Moscow Region but also for the development of a number of large cities in Russia.

\section{REFERENCES}

1. G.M. Lappo, "Urbanizatsiya v Rossii ["Urbanization in Russia]. Ekologiya urbanizirovannykh territorii, vol. 1, 2006, pp. 6-12.

2. E.A. Akhmedova, "Sovremennyi generalnyi plan goroda i vozmozhnosti ego realizatsii v usloviyakh rynka" ["Modern Master Plan of the City and the Possibility of Its Implementation in the Market"]. Promyshlennoe i grazhdanskoe stroitelstvo, vol. 8, 2010, pp. 6-10.

3. Yu.V. Kogan, "Tipizatsiya zhilykh territorii stolitsy dlya otsenki vliyaniya programm zhilishchnogo stroitelstva na ee gradostroitelnyi potentsial" ["Typification of Residential Areas of the Capital to Assess the Impact of Housing Programs on Its Urban Potential"]. Promyshlennoe i grazhdanskoe stroitelstvo, vol. 6, 2013, pp. 11-13.

4. I.G. Lezhava, "Goroda Rossii. Problemy proektirovaniya i realizatsii" ["Cities of Russia. Problems of Design and Implementation"]. Promyshlennoe i grazhdanskoe stroitelstvo, vol. 5, 2013, pp. 3-10.

5. K.V. Kozlov, and V.V. Leonov, "Obespechenie stroitelstva obektov gorodskogo zakaza inzhenernoi infrastrukturoi" ["Ensuring the Construction of Urban Infrastructure Engineering Infrastructure"]. Promyshlennoe i grazhdanskoe stroitelstvo, vol. 6, 2013, pp. 35-37.

6. A.V. Aleksanin, and S.B. Sborshchikov, "Upravlenie stroitelnymi otkhodami na osnove sozdaniya spetsializirovannykh logisticheskikh tsentrov" ["Construction Waste Management Based on the Creation of Specialized Logistics Centers"]. Promyshlennoe $i$ grazhdanskoe stroitelstvo, vol. 2, 2013, pp. 66-68.

7. N.N. Mogosova, and T.A. Vorobeva, "Osobennosti otsenki zagryazneniya atmosfernogo vozdukha dioksidom azota ot peredvizhnykh istochnikov v g. Moskve" ["Features of Assessing Air Pollution with Nitrogen Dioxide from Mobile Sources in Moscow"]. Ekologiya urbanizirovannykh territorii, vol. 1, 2014, pp. 83-88.

8. T.E. Trofimova, and E.N. Turanov, "Nuzhno li znat i kak rasschitat skorost vetra na territorii goroda" ["Is It Necessary to Know and How to Calculate the Wind Speed in the City"]. Vestnik razvitiya nauki $i$ obrazovaniya, vol. 3, 2012, pp. 60-64.

9. V.V. Aleksashina, and K.K. Kartashova, "Problemy tverdykh bytovykh otkhodov (TBO) v megapolise (na primere Moskvy)" ["Problems of Municipal Solid Waste (SHW) in a Megacity (by the Example of Moscow)"']. Ekologiya urbanizirovannykh territorii, vol. 4, 2014, pp. 59-67.

10. V.V. Vladimirov, "Ekologicheskii imperativ goroda" ["Ecological Imperative of the City"]. Promyshlennoe i grazhdanskoe stroitelstvo, vol. 7, 2013, pp. 114-115.

11. Yu.M. Kossoy, "Spetsifika gorodskogo transporta i ekologiya urbanizirovannykh territorii" ["The Specifics of Urban Transport and the Ecology of Urbanized Territories"]. Ekologiya urbanizirovannykh territorii, vol. 1, 2007, pp. 67-69.

12. A.I. Finogenov, and A.V. Popov, "Concept of Planning Development of Coastal Resort Settlements under Conditions of Complex Relief", Journal of Environmental Management and Tourism, vol. X(1(33)), 2019, pp. 135-139.

13. D. Vlasov, "The Chance of Transport Behavior Paradigm in the Largest Cities of Russian Federation". In IOP Conference Series: Earth and Environmental Science 2. Ser. "International Conference on Sustainable Cities", 2017, p. 012017.

14. A.V. Abakumova, "Sposoby optimizatsii promyshlennykh territorii" ["Ways to Optimize Industrial Areas"]. Promyshlennoe i grazhdanskoe stroitelstvo, vol. 11, 2013, pp. 37-39.

15. S.V. Argunov, "Otsenka effektivnosti realizatsii gosudarstvennoi programmy "Gradostroitelnaya politika"” ["Evaluation of the Effectiveness of the Implementation of the State Program "Urban Planning Policy"'”]. Promyshlennoe i grazhdanskoe stroitelstvo, vol. 6, 2013, pp. 7-8.

16. A.L. Ignatiev, J.A. Khorkina, and K.I. Kolmykov, "Razrabotka sistemy monitoringa realizatsii Gosudarstvennoi programmy goroda Moskvy "Gradostroitelnaya politika"'” ["Development of a System for Monitoring the Implementation of the State Program of the City of
Moscow "Urban Planning Policy"'’]. Promyshlennoe i grazhdanskoe stroitelstvo, vol. 6, 2013, pp. 18-20.

17. S.I. Lyovkin, "“Gradostroitelnaya politika" v sisteme otraslevykh gosudarstvennykh programm" [""Urban Planning Policy" in the System of Sectoral State Programs"]. Promyshlennoe i grazhdanskoe stroitelstvo, vol. 7, 2013, pp. 5-8.

18. A.Yu. Butyrkin, A.V. Chernyshev, and K.P. Graboviy, "Kharakternye aspekty zhilishchno-kommunalnogo kompleksa kak slozhnoi organizatsionno-ekonomicheskoi sistemy" ["Characteristic Aspects of the Housing and Communal Complex as a Complex Organizational and Economic System"]. Vestnik MGSU, vol. 2, 2014, pp. 196-202.

19. I.P. Epifanova, and V.F. Gopko, "Organizatsiya sistemy upravleniya otkhodami v munitsipalnom obrazovanii" ["Organization of a Waste Management System in the Municipality"]. Ekologiya urbanizirovannykh territorii, vol. 3, 2009, pp. 60-64.

20. M.E. Butovskiy, "Organizatsiya bezotkhodnykh proizvodstv na urbanizirovannoi territorii - odin iz kriteriev ustoichivogo razvitiya krupnykh i bolshikh gorodov" ["The Organization of Waste-Free Production in the Urbanized Territory Is One of the Criteria for the Sustainable Development of Large Cities"]. Ekologiya urbanizirovannykh territorii, vol. 2, 2010, pp. 73-77.

21. N.L. Deriusheva, "Voprosy normirovaniya snegoplavilnykh punktov v sistemakh vodootvedeniya" ["Issues of Rationing of Snow Melting Points in Wastewater Systems"]. Ekologiya urbanizirovannykh territorii, vol. 1, 2014, pp. 76-79.

22. O.V. Padalko, "Tipovaya programma podgotovki promyshlennogo predpriyatiya $\mathrm{k}$ ego perevodu $\mathrm{v}$ rezhim chistogo (resursosberegayushchego, ustoichivogo) proizvodstva/potrebleniya" ["The Standard Program for Preparing an Industrial Enterprise for Its Transfer to the Regime of Clean (Resource-Saving, Sustainable) Production/Consumption"]. Ekologiya urbanizirovannykh territorii, vol. 2, 2007, pp. 68-71.

23. A.I. Finogenov, and A.Yu. Yakunin, "Printsipialnye napravleniya arkhitekturno-prostranstvennogo formirovaniya predpriyatii po pererabotke promyshlennykh otkhodov" ["The Principal Directions of the Architectural and Spatial Formation of Enterprises for the Industrial Waste Processing"']. In Sbornik nauchnykh trudov TsNIIPromzdanii Gosstroya Rossii [Collection of Scientific Works of the Central Research Institute of Industrial Buildings of Gosstroy of Russia], 1994, pp. 29-36.

24. V. Chulkov, G. Maloyan, A. Efimenko, and A. Kiselev, "Organizational-Technological Solutions, Risks and Reliability of the Preparatory Period of the Renovation of Territories". Advances in Intelligent Systems and Computing, vol. 692, 2018, pp. 367-375. 